\title{
100 the scent of memory: strangers, our own and others
}

This article first appeared in 1999 in Issue 61 of Feminist Review and has been reprinted here as originally published.

Avtar Brah

\section{abstract}

Using, as a point of departure, Tim Lott's recent autobiography where he attempts to make sense of his mother's suicide of 1988 through a reconstruction of his family genealogy, this article tries to map the production of gendered, classed, and racialized subjects and subjectivity in west London. It addresses the tension between Lott's discourse of his own white working-class boyhood during the 1970s where questions of 'race' are all but absent, and the racialized 'commonsense' that pervades the interviews with other local white contemporaries of Lott and his parents. These narratives are analysed in relation to the socio-economic context and the political activism of the period. Theoretically, it analyses the 'diaspora space' of London/Britain, interrogating essentialist 'origin stories' of belonging; reaching out to a glimmer on the horizon of emerging non-identical formations of kinship across boundaries of class, racism and ethnicity; and exploring the purchase of certain South Asian terms - 'ajnabi', 'ghair' and 'apna/apni' - in constructing a nonbinarized understanding of identification across 'difference'.

\section{keywords}

biography/autobiography; memory; interpellation; posthumanist subject; whiteness; class; gender; ethnicity; racism; Asians; Blacks 
They all crossed into forbidden territory. They all tampered with the laws that lay down who should be loved, and how. And how much.

(Arundhati Roy in The God of Small Things)

This essay is a meditation through a series of questions. A meditation, by definition, cannot pre-suppose answers or conclusions. I hope that this one develops into an open-ended conversation - a kind of graffiti without finite beginnings and endings - with $F R$ readers responding, interrogating, critiquing, agreeing or disagreeing, and extending its main concerns through the pages of this journal. The question: 'What do you think'?, which is scattered throughout this text, is, therefore, offered as a genuine invitation to write back. My own meditation is in pursuit of what Donna Haraway so aptly designates as the need to consider how humanity might have a figure outside the narratives of humanism. What language, she asks, would such a 'posthumanist' figure speak?

I want to set aside the Enlightenment figures of coherent and masterful subjectivity, the bearers of rights, holders of property in the self, legitimate sons with access to language and the power to represent, subjects endowed with inner coherence and rational clarity, the masters of theory, founders of states, and fathers of families, bombs, and scientific theory ... and end by asking how recent intercultural and multicultural feminist theory constructs possible postcolonial, nongeneric, and irredeemably specific figures of critical subjectivity, consciousness, and humanity - not in the sacred image of the same, but in the self-critical practice of 'difference', of the I and we that is/are never identical to itself, and so has hope of connection to others.

(Haraway, 1992: 87)

This would seem to be one of the most important tasks facing feminisms at this point.

\section{triggers}

In late 1996, the British Sunday newspaper The Observer carried a review of a book titled The Scent of Dried Roses. The newspaper contained some excerpts from this autobiographical account by a son of his mother's suicide. What caught my eye were the contents of the mother's suicide note, especially the following line: 'This will be so bad for everybody but I hate Southall, I can see only decay. I feel alone'. This sentence reverberated in the quiet of the Sunday morning compelling me to read the book. But why?

The word 'Southall' - ringing loud and clear in my ears - connected me across diverse, even disparate, life worlds to 'Jean' - this 57-year-old white woman who took her own life in March 1988. But, what kind of a connection was it that beckoned me inexorably into her world? What clues did I expect to pick up about this woman by reading her son's account of her life? This was not really a question about the reliability of his account, not least because, there is no 
guarantee that Jean's own account of her life would have rendered her any more transparently 'knowable' to me. The extent to which she becomes 'knowable' is not simply a matter of putting together fragments of information available about her according to some pre-given formula; nor can the task of making sense of Jean's universe only be an issue about the conceptual frameworks available to us for interpretation. Knowing is not so much about the assemblage of existing knowledge as it is about recognizing our constitution as 'ourselves' within the fragments that we process as knowledge; 'hailing' and being 'hailed' within the discourses that produce us and the narratives we spin; directing our socially, culturally, psychically and spiritually marked focus of attention upon that which we appropriate as 'data' or 'evidence'. Hence, 'data' are neither more nor less reliable simply because of the nature of their source: whether the source in question is autobiography, biography, history, religion or science. The boundaries between cosmology, history, religion and science are far from clear cut as they are no more, and no less, than different ways of trying to know that which defies transparency. For example, what is 'history' if not an on-going contestation of the very terms whereby the term itself emerged as a technology of eurocentric gaze. So that, a specifically embodied European subject such as Hegel could assert without an iota of self-doubt that Africa had no 'history'? What kind of a 'knowing' is this, where all human history is reduced to 'history'?

My point is that, what is humanity if not an intricate mosaic of nonidentical kinship?

Who was Jean? Is this a question about her alone? Why am I so exercised about this woman's fate? How am I implicated in her world and she in mine, by my asking of this question? Is my interest in her driven by a sense of affinity with her or by a sense of difference? Indeed, do these have to be bi-polar alternatives? Clearly, these are not questions that can easily be accommodated within the frame of modernity's imperatives of rationality. As I tried to understand my agenda for reading the book, I gradually became aware that my reasons for wanting to 'read' Jean could in turn be 'read', at least in part, as an alibi for a certain desire: the desire of colonialism's Other to 'know' how differential forms of 'whiteness' are 'lived'? In a way, I was (am?) constructing her as my window on to 'working-class English whiteness'. But it was not just that. Which other, more intimate, cords had she touched in me?

What made Jean hate Southall?, I asked myself. Could one of the reasons be that it is one of those localities of London where the post-Second World War immigrants from Britain's former colonies - especially those from South Asia came to settle in significant numbers? Was she among the white parents who in 1965 campaigned for bussing Asian children out of Southall schools if their numbers rose to one-third of the school population, because they were thought by these parents to 'hold back' white children? Was she at all like some of the white parents whom I interviewed as a research student in 1976? I had spent a 
considerable part of 1976 talking with 15-year-old students in three schools and their parents at home while trying to study the interplay - in the lives of 'whites' and 'Asians' - of the discourses of race, ethnicity and class in naming identity (Brah, 1979). For several months I had sat in classrooms, observed what went on in school grounds, walked the streets and visited homes in Southall, Ealing and Greenford. All this had left indelible impressions of this heaving, bustling, culturally thriving locality of west London which was 'home' to a range of groups: Irish, Welsh, Polish, South Asian and Caribbean descent groups alongside the 'English'. Jean was certainly within the same age-group as most of the white parents I had spoken to. Most of these parents had been incredibly outspoken and forthright in recounting what they thought about Asians in Southall. In some cases, my face-to-face presence during interviews seemed to be completely obliterated, as if I did not exist, while they heaped a variety of stereotypic constructions upon Asian populations. Did Jean experience them/us/me as a 'threat' in the same way as politicians such as Powell and Thatcher had been making out? Or could it be that her daily contact with Asian children through her job as a 'dinner lady' in a primary school with a predominantly Asian school population, fostered bonds of connection and affection which served to refute the appeals of an essentialist Britishness of the Powellian-Thatcherite variety?

\section{origin stories}

One 'white' mother whom I interviewed in 1976 had said to me: "Where did they come from"?, my father used to say, "they were here, and then the shops opened up"'.

The 'they' in this locution signified 'Asians'. 'She means people like me', I had thought to myself, feeling acutely 'othered', as my efforts at maintaining 'objectivity' (which my supervisor at university had insisted was critical for gaining academic credibility for my research) fast receded. I could not be a disinterested listener, although I listened attentively. My intellect, feelings and emotions had all been galvanized by my respondent's discourse. I was framed within it, whether I liked it or not. What was it that made her referent 'they' instantly recognizable as 'Asians' to us both? I did not know her ethnicity. She could have been English, Irish, Welsh, Polish or anything else in terms of her own 'background'. South Asians or 'people of colour' in general were not the only substantially large 'immigrant' group in Southall. Nor were they necessarily the most recent. The Southallian population at the time was continually renewed by, for instance, Irish immigrants. So, what was it that 'rang a bell' in the core of our sense of ourselves or 'interpellated' us relationally, simultaneously, with the result that we both understood who the 'they' in our conversation was? What nonlogocentric discursive spatiality produces such electric moments of 'recognition'? 


\section{a digression through the idea of 'interpellation'}

With regard to this question, I believe that there is much that is still of value in the Althusserian idea of 'interpellation', the concept that struggles with some of what I am trying to grapple with here, namely the making sense of being situated and 'hailed' socially, culturally, symbolically and psychically, all at once. I am mindful of the critiques of Althusser's conceptual framework (cf. Hindess and Hirst, 1975; Laclau and Mouffe, 1985). Indeed, I too have some serious reservations about aspects of this discourse, including its economic determinism 'in the last instance', its class-centricity and its structuralist formalism. Yet, to hold such reservations is not to deny the importance of economic and class relations.

A significant strength of the Althusserian discourse is that it takes seriously the relationship between the social and the psychic in the production of class subjects. It tries to stage a critical and non-reductive dialogue between and across 'consciousness' (or 'conscious agency'), 'subjectivity' and 'identity'. The analytical reach of the combined Althusserian theoretical repertoire is profound, with its key concepts ranging from the notion of 'historical conjuncture', as the outcome of articulation of contradictions that defy simplistic reductionism; through the idea of 'overdetermination', as the modes of articulation incorporating a symbolic dimension and a plurality of meaning; to the concept of 'articulation' itself, as a metaphor used to indicate relations of linkages and their effects across different levels of socio-cultural formation such that, as Stuart Hall notes, 'things are related, as much through their differences as through their similarities' (Hall, 1980: 320). The concept of articulation also embodies Saussure's insight that language is not a reflection of the world but produces meaning.

Hence, Althusser's claim that everything in the social is overdetermined highlights the processes whereby the social constitutes itself in and through the symbolic. And, therein lies the importance of the Althusserian reworking, following Gramsci, of the concept of ideology as signifying, not false consciousness, but referring, instead, to the complex matrices of meaning, concepts, categories and representations in and through which individuals make sense of the world. That is to say that, individuals are 'hailed'/'interpellated' within and across universes of representations and discourses of meaning in the process of our constitution into cultural/social subjects. The importance of the poststructuralist critique of the concept of ideology notwithstanding, I read interpellation as the process of signification whereby we come to 'live' (albeit largely unconsciously) our symbolic and psychic relationship to the social. I have sympathy with those critiques of the Althusserian paradigm which take issue with the functionalism embedded in his discussion of the relationship between 'interpellation' and the 'Ideological State Apparatuses', but the concept of interpellation itself remains pertinent and useful. It places the question of the relationship between effects of capitalist social relations and subjectivity into the realm of productive interrogation. 
A far more serious limitation of Althusserian structuralist Marxism, in my view, resides in its lack of attention to questions of women's gender (for the male gender is its norm), racism, ethnicity and sexuality. My encounter with Jean within the pages of a Sunday newspaper and later in her son's autobiography, or with the white mother whom I had interviewed two decades earlier, cannot be understood outside of these 'other' contexts.

$* * *$

'... "Where did they come from"?, my father use to say ...'.

One straight answer would be that which was encapsulated in the contemporary political slogan: 'We are here because you were there'! This slogan referred to the history of British colonialism and imperialism, which resulted in Britain turning to its former colonies for the recruitment of workers to meet the post-Second World War labour shortages that befell capitalist economies of western Europe. Was my 'research respondent' familiar with this history? She easily might not have been, given, as I discovered during my research, a spectacular amnesia on this matter within the curriculum of Southall schools of the period, and presumably earlier. More worryingly, the school library in one of the three secondary schools still stocked reference books which discussed the anti-colonial Rebellion of 1857 in terms of the 'Indian Mutiny' and the 'Black Hole of Calcutta', without any evidence indicating that such texts were being subjected to critical scrutiny. But even if we assume, for the sake of argument, that my interviewee was singularly familiar with the history of British imperial adventures abroad, we cannot automatically deduce how such evidence would have been interpreted by her. Facts do not speak for themselves. How was she 'interpellated', as a workingclass white woman with her unique autobiography, within the imperial discursive formations? Indeed, how did colonial discourses figure in the production of her subjectivity? How did they mark the minutiae of her everyday life? How and when did her father's rhetorical question, and the sense of threat and discomfort it conveys, become her own sense of her self?

We do not have the detail necessary to attempt any definitive answers (if, indeed, such a thing were ever possible). But some clues are available from the combined narratives of working-class white parents and school-students I interviewed. A local (but not entirely localized) form of Gramscian 'commonsense' - fragmentary, fragmented and contradictory but one that could not be dismissed as irrational within the terms of its own internal logic - may be gleaned from their commentaries. The refrain of 'too many coloureds', 'within a month they were here like bees', and 'they have taken over' and so on is a major theme within these representations. As one 15-year-old white boy said to me:

Southall is too overpopulated with them. Such a lot of them. It is alright if they move up to Birmingham, somewhere different because they all like to come in one place ... It makes 
some people not like them and they move out of the area. Some people can't afford to move and they are stuck by themselves.

What economists, sociologists or geographers described as the 'white flight' from declining inner- or outer-city areas by upwardly mobile sections of the white working class in a period of economic boom, is experienced by those who remain as a sense of having fallen behind those able to leave, 'stuck by themselves'. The resentment towards the upwardly mobile fellow whites is projected on to Asians and other 'people of colour' who are now blamed for the departure. The reams written about the role of global capitalism and unequal development in underpinning contemporary labour migrations have little resonance in this explanation. They do not form part of the 'commonsense' of this beleaguered identity.

\section{A 15-year-old white girl confessed:}

I think they have taken over Southall. I suppose people just don't like the way they live, the smell of their food, it gets down your throat because you are not used to it. It is not so tidy as it used to be. I think they have mucked it up a bit really. A lot of old people, they complain, they say it used to be a nice country place and everything, and they have taken over all the shops, and it is horrible round here now.

Here we encounter feminized commonsense with its fantasy of tranquil and tidy rural domesticity which is 'mucked up', disrupted by the 'intruders' with their alien foods and unfamiliar smells. There is an overwhelming feeling of being 'taken over', of being soiled and defiled, of things being 'horrible'. The 'intruder' is discursively embodied as a form of aggressive masculinity. This discourse constructs Southall in terms of a vulnerable feminized space and displaces female anxiety about male aggression into a fear of the colonialism's 'Other'. This is partially achieved by transmuting colonial immigrant labour into the figure of 'colonizer': Asians come to be represented as having 'taken over', as the discourse converts the transgressed-against into the transgressors.

In contrast to the somewhat 'indirect workings' of racialized discourses in the girl's narrative, a father-son pair, conversing with me at their home, are positioned within an explicit and overt discourse of 'racial' superiority:

Father: We have emigrated to other countries. Educated them, raised their standard of living, but they are allowing in too many. The black man is getting more educated and the white man doesn't like it. I was brought up to believe that the black man was a slave. Now they want the same standard as us! We don't like it.

Son: We resent them and we will influence our children. Even when I was five, you'd mix with them in school but never have them in your house. It is colour, not culture. You always feel you are white, you are are brown, you are black. 
Far from being understood as a source of regret, the tales of colonial exploits and exploitation are refracted here through the ideology of 'civilizing mission' and absolutist racialized difference, and experienced as an inter-generational form of male-bonding between father and son, while holding at bay the painful reality of the inferiorized position of working-class masculinity: 'the black man is getting more educated (i.e., getting ahead in class terms), and the white (working-class) man doesn't like it'. The discourse of racial superiority may be understood here as displacing class antagonism while the father and son are transported into the realm of imagined and imaginary class-less and unified Englishness.

Similarly, a three-way discussion between myself and the parents of another student, steers into focus the inconsistencies, dissonance, disavowal and contradiction within the logic of narratives marked by racialized discourse:

Mother: I am moving out because there is no future for my children in Southall. There are no shops or other facilities.

Father interjects: The facilities are there but proprietors have changed.

Mother: Indian shops are over-run by mice. We never used to get mice in our house until the Asians moved in next door. Look at their garden. It is filth.

Father protests: Our own garden too is over-run by weeds!

Mother: Ours is just overgrown. Theirs is filth and dirt. (emphasis added)

The imagery of vermin, dirt and filth is common enough in representations of all kinds of 'Others'. Here, it would seem to feature as a way of disavowing one's own sense of failure symbolized by the unkempt 'garden' while the neighbour's garden becomes the bearer of this self-disgust: 'Ours is just overgrown. Theirs is filth and dirt'. The very fact of having Asians as neighbours itself serves as a signifier of decline in this discourse. As regards future prospects for the children, it is arguable that the future of all children in this working-class London suburb in the throes of a recession at the time was far from sanguine. But the term 'future' may be understood as holding a double meaning here: referring to general prospects as well as to 'racial' destiny. A deeply felt concern that the more 'successful' white person was in a position to exercise the option of moving out is at the heart of this expression of acute anxiety. The father's interjection highlights inconsistencies within the discourse, but such contradictions are shored up by the mother's denial.

On the other hand, disavowal and denial are not the only vehicles for 'othering' processes. A subjective sense of resentment may persist even when the 'conditions underlying the recruitment of immigrant workers' and their 'contribution to the economy' is fairly explicitly invoked. Invocation, after 
all is not always the same as acknowledgment. Another mother, for example, observes:

I was in Southall when the Indians came. They were brought in as cheap labour. They don't want to mix with us; don't try to learn the language. We try to get on. We feel resentful. My mother says that we were kicked out of India, now they are all here. People blame them for the economic crisis. But, our economy would fall down if they all went home. Who would run our buses, and our hospitals?

This discourse references the economic context within which workers from former colonies were recruited as replacement labour for jobs that white workers had abandoned in response to better opportunities provided to them by the post-war economic boom. It is couched within an acceptance, no matter how ambivalently articulated, of the proposition that the economic crisis of the late 1970s could not be blamed upon Asian or Caribbean descent people in Southall. Nonetheless, these populations come to embody the site of difference and unfamiliarity where 'old ways of doing things' are in crisis. English ambivalence towards mixing with 'outsiders' and learning 'a new language' of communication is projected onto groups who, if the contemporary evidence of a thriving programme of classes in English as a Second Language is to be taken seriously, were exceedingly busy trying to learn English, as well as the wider cultural language of a rapidly changing late capitalist social formation. But everyday commonsense of this discourse is not especially concerned about these seemingly 'distant' issues: 'we feel resentful', and a (mis)reading of the process of decolonization, 'we were kicked out of India, now they are all here', legitimates the logic of resentment.

How do we change this 'distanciation' of the 'macro issues' into more intimate conversations that foster connectedness and understanding?

This brief foray into excerpts from certain narratives - recorded in the 1970s Southall Jean would have been familiar with as the mother of teenage sons - is not intended to suggest that there was a coherent, homogeneous or unidirectional racialized discourse circulating in Southall; or to argue that the respondents involved were misinformed, irrational, bigots. On the contrary, the point is precisely that the white young people and their parents were 'ordinary' (in Raymond William's sense of the term), everyday folk like you and me. Several admitted to having Asian and African-Caribbean descent friends, and a few counted individuals with these backgrounds as among their relatives. But none of this can be taken to work as a necessary inoculation against states of mind, emotions, values and practices which may have ethnicist or racist effects. For example, a white mother with an Asian child is not, by definition, immune from positionality within racialized discourses and practices. Rather, the issue is much more about the position that we politically (in the widest sense) come to practise, and not merely espouse, as we 'live' (both consciously and unconsciously) the vicissitudes of our lives. 
And, is this not one of the most difficult things to do, positioned, as each and everyone of us is, in some relationship of hierarchy, authority or dominance to another? How do we construct, both individually and collectively, non-logocentric political practices - theoretical paradigms, political activism, as well as modes of relating to another person - which galvanize identification, empathy and affinity, and not only 'solidarity'?

'... Where did they come from? ...'

Stories of origin abound in Southall as elsewhere. The local library stocks a pamphlet which holds that the 'Saxons' were one of the first to leave a permanent mark on this area (Kirwan, 1965). The name 'Southall' is said to be of Saxon origin, meaning the south corner of a stretch of land. Were they not a linguistic group then, instead of a separate 'race' as racial typologists claim? The Saxon invaders, according to this chronicle, were followed by the Danes, and later by the Normans. (And, '... Where did they come from? ...', I ask you). Until the nineteenth century, the majority of the inhabitants of Southall depended on agriculture for their livelihood. It is suggested that the farmers in the area were probably converted to Christianity by the missionaries of St Augustine in the eighth century. About this time, parishes were marked out and Southall became part of the 'Precinct' of Norwood. Southall began to lose its rural character during the late seventeenth century. The process would seem to have been initiated in 1698 when an influential local family succeeded in gaining a charter to hold a weekly market in the area; even today a market is still held on the same site. With the construction of a canal between Uxbridge and Brentford, and the building of the railway in 1838-1839, Southall rapidly developed into an industrial town. The growth of industry and the availability of good transport facilities have played a critical role in attracting mobile labour to the area. Before the Second World War, the Irish and the unemployed from south Wales and the north of England constituted the major source of outside labour; immediately after the war, sizeable Polish enclaves also developed alongside South Asian and African-Caribbean groups. During the 1990s, the existing populations have been augmented by refugee groups, most notably from Somalia.

Who, in this fragment of global migrations, can claim to be 'native' of Southall?

The reason generally offered by academic discussions for the arrival of Asians in Southall during the 1950s was the availability of work at a rubber reconditioning plant, the Woolfs rubber factory, in Hayes, very close to the border of Southall. Owing to the unpleasant working conditions and the need for shift work, the company found it difficult to recruit white labour. During the Second World War, the personnel officer at Woolfs had apparently fought alongside Sikhs in the Middle East, and had been impressed by them. This ironical encounter between the colonizer and the colonized, away from 'home' on an imperial battlefield, was often cited to me by professionals working in the area as a watershed in the 
policy of hiring Asians. Soon, these workers were to combine into the Indian Workers Association and engage in a very British trade union activity of the period, mounting campaigns for unionization and improvement in working conditions (Harrison, 1974). Yet, as we have seen above, class solidarity did not figure strongly in the white parents' accounts. A few of the white parents were born during the economic depression of the 1930s, and several recounted family and neighbourhood stories of hardship and scarcity. They spoke of the tradition of fierce pride with regard to skilled work which meant that a skilled worker would rather remain unemployed than engage in unskilled forms of work. In academic-speak the working class was internally fractured by the hierarchy marked by occupation skill and the ambition to succeed in life. It was also equally differentiated by gender and other modes of differentiation. But these internal fissions would be subsumed within the boundary of 'us' when facing comparison with the middle classes. As a working-class locality, Southall was overshadowed by the more affluent, middle-class suburb of Ealing. As a community worker explained:

Oh, yes there has always been a feeling of 'Us against Authority' - that the rules were imposed from outside and pushed onto them. There was very much the element that Southall was the back-end of Ealing. Southall residents would get angry, would resent it. It was a dig and it made them even more united.

According to the women, Southall was a close-knit community and social control was stringent. One woman told me:

\footnotetext{
Most people lived and worked here. A lot of your relatives were in Southall. Most people knew one another. You couldn't do anything without everyone knowing about it. We wouldn't dream of going into Ealing when we were youngsters - right up till I was 21 . Sunday night it used to be the community center ... I don't have a clue what they do there now. Saturday we used to be at the Dominion Cinema. That used to be a cinema for us, with a dance hall at the top which my aunty used to be the manageress of.
}

The point about not having a clue as to what 'they do there now' and, that the Dominion 'used to be a cinema for us' is a reference to the fact that when the popularity of television during the 1960s resulted in a drop in the cinema-going white audiences, the Dominion was bought by the Indian Workers Association to hold Asian community events, including the showing of Indian films. Notwithstanding the fact that it was the play of economic markets which governed this 'take-over', what registers with segments of the white population is the fact that the Dominion was now owned by an Asian organization. Asians are thus constructed as having usurped what is perceived by the white residents as their community resource. If previously, intra-class boundaries were the primary signifier of 'difference', it is a racialized form of ethnicity that now moves centre-stage as the major axis of differentiation. The 'pub', a classic gendered 
signifier of working-class sociality, becomes the point of condensation in naturalizing such 'difference':

You don't find the white people going into the Victory. The Victory is for the Asians, the Black Dog is for the Jamaicans. We wouldn't dream of walking into the Victory or the Black Dog. That's just not on - we don't do that. We used to go to the White Swan - now it is mixed. We go to the White Hart over the bridge, which is ours, and the George is Irish. It's all segregated.

This multilayered discourse embodies the contradictory relationality of 'race', gender, class and differentialized ethnicity in the post-colonial spatiality of Southall. The figure of the 'pub' articulates 'power-geometries of spatiality' (Massey, 1999) along these different signifiers of 'difference'. Its symbolism, partially communicated through the semiology of animal imagery, simultaneously demarcates, transgresses and erases a multiplicity of borders. The 'we' here is a certain Englishness, differentiated from Irishness, with the 'difference' of the latter signalled by 'The George'. The discourse marks the heterogeneity of 'whiteness', but it is a malleable boundary compared to that constructed against the 'Other' colour(s): 'we wouldn't dream of walking into the Victory or the Black Dog'. But, the 'Other' colour(s) is/are both similarized and differentiated: the Asian emerges as the victor, viewed as the 'colonizer', as we have already seen. The 'Jamaican' referring to African descent black people, on the other hand, is 'interpellated' across the long established racist imagery of the African as closer to animals: the image of 'Black Dog', saturated with racialized meanings, conveys a sense of domesticated savagery. While this commonsense discourse consciously invokes a situation where 'it's all segregated', it simultaneously undoes this claim by foregrounding subconscious anxieties about what might be going on at the 'White Swan', the feminine figure of racial and sexual purity, where the clientele is now 'mixed'. The White Swan was also the site of class ambivalence, for it attracted a higher class of 'racially' mixed clientele, 'not the general run', as one woman explained to me, to be found at the Victory, the Black Dog, the George, or, more significantly, at the White Hart - the very heart within this representation of this particular variety of working-class Englishness.

'... Where have they come from? ...'

The immediate context for the question was the summer of 1976. Which 'other' genealogies of Southallian Englishness, the ones in which my own Africaness/ Asianess/Californianess/Englishness/Panjabiness, are allusions/illusions in this question? I can only sketch a few features here. As I retrace, certain contours begin to take shape: bodies, landscapes, sights, smells; sensations of fear and threat, of belonging, unbelonging and sometimes alienation; of familiarity and estrangement, of love and hate; memories of blood on the streets, excitement of political mobilization and optimism that comes in the wake of daring to imagine 
futures of hope when confronted with despair. Some memories, in particular, stand out. In Southall, Gurdip Singh Chaggar, a 15-year-old boy returning home from school is stabbed to death in front of the Dominion Cinema in April 1976. His death sends shock waves among Asian communities of Southall, and it produces a resounding response as they (we) came out in force to demonstrate on the streets of Southall. At first, the media reports suggest that the attackers are three 'white' teenage boys. Some political activists discuss the incident as primarily a question of class - working-class communities torn apart by the dominance of the ruling classes. Then the media refer to one of the three as being 'mixed race' - in this case, meaning that he had one black and one white parent. His colour, light brown, becomes quite a significant political talking point. For some people this boy's involvement was a signal that this was not a racist murder, as if racism is coded in our genes. This position is not surprising, however, given that even in the late 1990s certain eminent socio-biologists continue to champion their troubling and troublesome theses about 'selfish genes', 'homosexual genes' and so on (cf. Rose, 1997 for a brilliant critique). For other commentators, this was a racist murder except that the brown boy had been deluded into thinking that he was white like his friends. But, while all positionality within discourse involves some disillusion on all our parts, racist or other effects of practices, whether they be scholarly treatise or actions such as stabbing, do not depend for their effectivity on the agent necessarily having to be white, gentile, male or heterosexual (although of course these subject positions are implicated in the construction of racialized, gendered or sexualized forms of power). If this were the case, we would not have any hope of, say, a white person ever being non-racist, or someone engaged in heterosexual practice ever being non-heterosexist.

While the political commentators, media pundits and community activists debated the murder, the dead boy's mother wailed in agony the question: 'Why'? This is a question that no feminism worth its salt, can refuse to address.

In East London, the proverbial 'gateway' into the 'heart' of London for a variety of immigrants over the centuries, incidents of racist attacks and violence continue to escalate throughout the 1970 s resulting in several cases of death. Two male students from Mile End are killed in 1976. During 1978, three men Altab Ali in Whitechapel, Kennith Singh in Newham and Ishaque Ali in Hackney all die from wounds inflicted during street attacks. These deaths galvanize the East London Asians as well as some Left organizations into public demonstrations (Bethnal Green and Stepney Trades Council, 1978). In Notting Hill, there are massive confrontations in the summer of 1976 between the police and Black young people as the latter try to stake their claim to this inner-city enclave of central London where dire poverty jostles with fantastic wealth. The summer of 1976 was dubbed by the media as the 'long hot summer' as they relayed reports, television footage and photographs of African and Asian descent protesters 
demonstrating publicly their anger and frustration at overt and covert forms of racism that were all but ignored by agencies of the state and rarely debated in public policy or other political forums, aside from certain research organizations. These public demonstrations were conspicuous, among other things, for the involvement of British-born young Blacks and Asians who were asserting a new British political identity. Britain 'turned a different colour' in a million senses of this phrase, as Powellian constructions of 'whiteness' - British=White - were publicly interrogated, challenged and decentred: a gesture that wordlessly, but not silently, declared 'we are not just "in Britain" but rather are "of Britain", and we don't even care whether or not you agree'.

'... and then the shops opened up ...

The high street of Southall in the late 1970s, as today, is indeed peppered with Asian-owned shops selling dazzling saris, beautiful salwar-kameez, exquisite gold jewellery and restaurants offering all manner of delicious South Asian cuisine. To a casual visitor, of whom there are frequently many in Southall, the street exudes an atmosphere of wealth and prosperity. To the local white residents, the majority of whom are working class, this apparent example of Asian entrepreneurship can easily seem, as we have already seen, like a 'take-over' because Britain in the 1970s is awash with constructions of 'the Asian' as an outsider par excellence. In the processes that mark the play of these signifying practices, local Asian shops become a sign of white working-class failure, a site of envy and desire. The 'Asian shop' assumes such a magnified visibility in the popular imagination that the presence on the high street of corporate businesses such as Marks and Spencer or Woolworths passes without comment. Even Woolworths, the chain-store owned by a USA-based firm, becomes 'our own' as against 'these Asian outsiders'. That is to say that chromatism of the racialized imagination spotlights Asian-owned small business as a threat while rendering global operations of corporate business colourless and invisible. Yet, contrary to what this defensive 'Englishness' of a beleaguered subordinate class imagines, the grass is not greener on the other side. The shops are a facade. Behind the cheer and sparkle there is the grim 'Asian reality' of high levels of unemployment, rampant low pay, with many businesses - often set up under the noose of high debt in order to avoid unemployment - teetering on the verge of liquidation; overcrowding, a general lack of public amenities and a growing presence of fascist organizations such as the National Front.

Which fragments of this reality did Jean connect with? With the glitter as if it were a transparent sign of wealth or with its opaqueness, signalling the much more complex and difficult terrain of hope, dreams, despair and desire eked out on the margins of low income and poverty, where lack of money can easily come to stand for personal failure. What kind of 'puzzle' of loss and desire is figured in her suicide? 
And the National Front comes marching in ...

1979 is the election year and the National Front is fielding enough candidates nationally to win prime-time on television for a political broadcast. Although the National Front had little support in Southall, they wished to hold an election rally in the local Town Hall. Despite petitions to the contrary made by local residents opposed to the fascists, the local authority grants them permission to hold their meeting. Escorted by the police, they begin their march shouting inflammatory slogans, calling for the repatriation of 'immigrants', a term that by now had become synonymous in popular consciousness with 'people of colour'. Their opponents have arranged a show of strength by planning a counter-march for the same day and a route is agreed with the local police. In the event, the antifascist marchers are blocked from following the agreed route by the Special Patrol Group Units of the Metropolitan Police. During the confrontations that ensue, nearly 700 (predominantly Asian) men and women of all ages are arrested and bussed out to police stations all over London. Of these, 344 are charged and tried in courts. The building occupied by a Black musicians' co-operative, including the band 'Misty in Roots', is raided by the police and the music equipment is all destroyed. The lawyers and the medical staff present are, according to their own accounts, forced out of the building amidst a barrage of racist and sexist abuse. Clarence Baker, the lead singer of Misty in Roots, is wounded and lies unconscious in hospital for some time. As a report notes:

2,756 police, including Special Patrol Group units, with horses, dogs, vans, riot shields and a helicopter were sent in ... the evidence of hundreds of eyewitnesses shows that ... police vans were driven straight at crowds of people, and when they scattered and ran, officers charged at them, hitting out at random. ... A Daily Telegraph reporter saw 'several dozen crying, screaming coloured (sic) demonstrators ... dragged bodily along Park View Road to the police station ... nearly every demonstrator we saw had blood flowing from some sort of injury; some were doubled up in pain. Women and men were crying'.

(Campaign against Racism and Fascism/Southall Rights, 1981: 2)

On that day, Blair Peach, a white teacher from East London, died from head injuries suffered, according to evidence presented to the courts, when he was hit by police officer(s) attached to the Special Patrol Group. I saw older Asian women file past his coffin, calling him 'put' (my son) as tears streamed down their agonized faces. He was no 'outsider', as far as they were concerned, although they did not know him. He was very much 'our own', laying his life down for a future where racist and fascist activity would not stalk their neighbourhood. The women's lament was no superficial gesture of sentimentality, as some forms of 'hard politic' might maintain. It was a profound expression of love and inclusion. One of the many creoles spoken on the South Asian subcontinent is Urdu which makes a distinction between 'ajnabi' and 'ghair'. An 'ajnabi' is a stranger; a newcomer whom one does not yet know but who holds the promise of 
friendship, love, intimacy. The 'ajnabi' may have different ways of doing things but is not alien. She could be(come) 'apna'; that is, 'one of our own'. The idea of 'ghair' is much more difficult to translate for its point of departure is intimacy; it walks the tightrope between insider/outsider. The difference of the 'ghair' cannot be fully captured by the dichotomy of Self and Other; nor is it an essentialist category. Yet, it is a form of irreducible, opaque, difference. Although these three terms may often be used in contradistinction to each other, they do not represent opposites. To the women who mourned Blair Peach, he was an 'ajnabi' but not a 'ghair'. He was 'apna'. The distinction is politically important. The world is full of ajnabis. There are feminists, for instance, whom I may never meet. They are 'ajnabi' but not 'ghair' because they are part of my imagined community. Unless, of course I meet one and she treats me as if I am 'ghair', because of, say, my colour. At that moment she steps out of my boundary of 'apne' (plural of 'apna': own kind) and begins to feel 'ghair'. We may continue to share political views. May even engage in common political projects. Yet, we will be divided by the boundary of 'ghairness' and our relationship will feel hollow. But, then again, her positionality could change - as has often happened through anti-racist projects - and the ghairness may be transformed.

In the aftermath of the events described above, Southall became the site of intense feminist, anti-racist and other forms of political activity. Southall Black Sisters was formed. The Southall youth Movement (a predominantly male organization) fought fascists but also came into conflict with feminist politics. Southall Rights and Southall Monitoring Group continue their advocacy work. A variety of Marxist groups, and various community organizations continue still to maintain their presence. But, political shifts marked by such terms as 'Thatcherism' (and now 'Blairism') have produced a significantly changed political terrain. This period, however, is not my focus of concern here, although I have discussed some features of this phase elsewhere (cf. Brah, 1987, 1996; Southall Black Sisters, 1989).

'... Where did they (we) come from? ...': an origin story of the late 1990s

13 July 1997, The Observer carries the headline 'How I braved academic derision to prove we're really Africans'. The subject of this headline is Chris Stringer, a paleontologist. Addressing the Observer readers, he writes how he was vilified when he first proposed the idea that 'they [the Neanderthals] are not our [read Europeans'] ancestors and humans are all Africans under the skin' (p. 12). So, are all Observer readers Europeans? That is an interesting presumption, or perhaps a subversive act begging the question about Europeaness. We are all, he says, Africans under the skin? The differences are only skin-deep? What does one do with the skin itself? What is the 'truth of the matter'? What is the matter of truth? The report outlines the controversy. Evidently it was generally accepted during the early 1980s, that early humans known as Homo erectus had indeed emerged from Africa but nearly a million years ago. Homo erectus, the story goes, 
wandered the world evolving into Neanderthals in Europe, Java Man in the Far East and Peking Man in China (what a spectacle of male cloning, long before our very own dear 'Dolly', the sheep, came to fame in 1997!). Chris Stringer accepted this hypothesis but only partially. Yes, Homo erectus had indeed evolved into the above eminent trio (where was women's lineage among all these men?), but they were not our immediate ancestors. Instead, Stringer contended that present day humans are all descended from a second wave of humans who also emerged from Africa but approximately 100,000 years ago and replaced all the rest.

Stringer's thesis was based on the study of bones. The occasion for Stringer's Observer article is research published the previous week using DNA samples from bones. These studies by Alan Wilson's team at the University of Berkeley would seem to confirm Stringer's hypothesis that Europeans could not claim a separate line of descent from Neanderthals. This new evidence appears to establish that we must all have had a common ancestor: 'an African Eve, that had strolled our homeland a mere 200,000 years ago'. The image of a beautiful African woman walking tall and strong across thousands of miles we today call Europe is gloriously appealing. What was her name? Was she called Eve? Is it important what she was called? What would she feel if she returned today to find that some of her ancestors were enslaved, colonized, ethnically cleansed, subjected to rape, murder, holocausts, and reduced to impoverished masses, largely because they were assumed to be 'different'. With which mother's tears would she cry? What collective achievements or acts of love, kindness, compassion, sensuality, beauty or creativity could we name that would bring a smile to her face? 'Mother, are we all the same or different?' How would she/you reply?

\section{the enigma of Jean}

Jean unexpectedly entered my universe one Sunday morning nearly 2 years ago. Today we 'inhabit' Southall together as she 'lives' in the intimacy of my memory. I never met her. She was clearly an 'ajnabi'. But, somehow she had not felt like 'ghair'. I wanted to know what had made her hate Southall, a place which I had experienced so differently. I was also deeply touched by her words: 'I feel alone'. I had heard that note on the lips of several Asian mothers I had interviewed that summer so long ago as they traced memories of rural Punjab or East Africa, places where they grew up. They spoke of the pain of separation from family, friends and the land they had known as 'home'; recounted the hardship of manual labour in London factories combined with the demands of 'woman's work' in the household; and, they described the pleasures as well as the trials and tribulations of having teenage children, just as Jean did. Their lives changed so radically when they boarded that plane to England. Stepping into Jean's neighbourhood was pretty traumatic for them. But, in time, Southall had become home and their locally born children were now approaching school leaving age. 
There was so much that all women in Southall 'objectively' shared. But we do not 'live' lives objectively, nor is this a straightforward question of false consciousness, as we have seen.

Tim Lott's book, as one might expect, is not so much about his mother as it is about his own attempt to make sense of her suicide. Within its own terms, this is an honest, meticulous, deeply moving account of a son's inquest into his mother's death through a reconstruction of his family biography. It is a gripping narrative of the changing features of class during this century as 'lived' by an extended family. It is a chronicle of the upper or well-off sections of the working class who are listed as C2 on the Registrar General's classification of occupation, a group with more money than the Ds and $\varepsilon s$, and a whole lot more ambition to succeed. Jean had been an attractive young woman with a beautiful cascade of chestnut brown hair which she loses in the early years of her married life due to alopecia. From then on, she wore a wig and never let anyone, including her husband and her children, see her without the wig. She even slept with a head scarf knotted tight in 'gypsy style'. What must it have felt like to live in fear of the 'wig' coming off? What constructions of female 'beauty' did Jean's mind occupy that she lived in terror of her 'camouflage' being discovered? It is only after her death that her son discovers how, as part of the treatment for alopecia, Jean had been prescribed a tranquillizer that was powerful enough to be used in serious cases of epilepsy. Later, for years, she was put on drugs normally used in cases of schizophrenia. The doctor's note speaks of 'emotional factors playing a part' in the condition that resulted in her hair loss.

What was Jean's condition?! The wider ramifications of this question are such that the question itself becomes virtually impossible to answer. Her suicide note points to a deep sense of alienation:

I cannot keep up with this pretense. We have had so many happy year's (unhappy years?) and I can see the strain this is having on you (the husband), in the end you will grow to hate me. So it is time to get out of your life. You have so much to give such a bright mind and I am holding you back. (comments in parenthesis added)

How far was the husband's 'lived' masculinity implicated in Jean's demise? This is not a question of apportioning blame, but rather a point about the psychological and emotional fallout of 'living' social relations of gender where the trope of 'good wife' works to make the woman feel so hopelessly inadequate that she must feel that she is 'in his way'.

In all this, Jean still remains an enigma, as she properly should. Who am I to 'analyse' Tim Lott's memory of a kindly and devoted mother? I still do not know how 'my kind' - the Asians - featured in her life world. The Scent of Dried Roses is largely silent about the questions that exercise me, which 'interpellate' me as a racialized gendered subject. Following Ruth Frankenberg, one could easily 'read' this book as a form of 'whiteness' that is blissfully oblivious of the 'social 
geographies of race' (Frankenberg, 1993: 54) which constitute 'white' as a privileged signifier. What are the implications of this repression? I believe that the effects of both 'writing out' and 'being written out' are devastating for all concerned. The repressed eventually returns.

There is such a great deal of, otherwise complex and sophisticated, writing published today that still continues to 'forget' its own constitution in and through the discursive interstices of 'race'. Lott is very aware of the nuances of how class colours life but without acknowledging the 'colour' of his own class as compared to that of 'people of colour'. He knows that, as Annette Kuhn argues, class is not only about income, the nature of your job, your accent, how you dress or how you furnish your home. It is more than that for: 'it is something under your skin, in your reflexes, in your psyche, at the very core of your being' (Kuhn, 1995: 98). Precisely! But, class does not operate independently of other axes of differentiation. It is gendered, raced, sexualized and so on, in precisely the same way. Accept that colour-based racialization is not merely under the skin. The colour of our skin is exactly what 'colours' us, our very being, across assymetrical power relations. Lott speaks of how he and his two brothers loathed Southall, mentions the Asian presence in passing and declares that the Whites and Asians were insular communities who were merely indifferent to one another. Is it mere indifference that leads to narratives such as those quoted above? Lott says that he and his brothers did not leave Southall 'because we disliked Asians':

No, we bolted because Southall was a dump, because it was nowhere, like most of
subtopian England. We hated it for the reasons we imagined our parents liked it - because
it was predictable, safe, conservative and limited in scale and possibility. We hated
because we could see that it didn't know what it was, or where it belonged, or what it was
for.
(Lott, 1996: 29)

There is not the space here to fully address this perfectly plausible commentary on 'escapes', but can it really be understood independently of the resentful Englishness, discussed earlier, articulated by his peers and their parents who could not 'bolt'; or, indeed, outside the context of his mother's attempt at 'final escape'. In any case, with regard to Jean here, I am far more concerned about the genealogy of 'staying put' in the 'diaspora space' (Brah, 1996) of Southall. Lott continues:

But Jean stayed, tending her isolated front garden, as the other gardens were paved over for car-parking space, as Sikh traditional styles - saris, turbans, salwar and kameez, dhupatas and guths - became more familiar sights than Aran sweaters or M\&S belted raincoats. She would nod and say hello, always be polite and friendly, chat over the fence to $\mathrm{Mr}$ and Mrs Mukhrejee at No. 29. Perhaps, she was secretly prejudiced, although she never said anything.

(Lott, 1996: 29) 
Perhaps, she was not 'prejudiced' at all, if she never expressed any such sentiment even to her loved ones. This is important to me. Like many of you, I have read scholarly treatises on prejudice and racism. I even confess to writing them! But, I have this fantasy that some disclosures - especially in relation to deep-seated feelings about issues of such unmentionables as racism or homophobia - are shared as secrets within the intimate space of friendship, family and 'community'. My study in Southall had offered me some glimpses, but I did not have access to the 'intimate' history of such phenomena. I think I had hoped that Tim Lott's book would provide me that entrée. I am none the wiser about Jean, except for what is contained in the above quite telling observation by her son. Her map of suburban England had radically changed, due to a million reasons: global and local economic restructuring; major political changes such as the impact of Thatcherism; the impact of new information technologies on daily life; and the broader social influence of late twentieth-century formations of globalization. There had been major cultural shifts rendering her kind of femininity in crisis (cf. Steedman, 1986; Hall, 1992; Skeggs, 1997). All this clearly had a deep and profound effect on her. The growing presence of Asians might have been disconcerting to her; they (we) might have assumed iconic significance within her understanding of these topographies of change. But, Jean did not demonize Asian presence. She did not blame 'us' for everything that had gone wrong in her life. OK, we did not become intimate. But, nor did she treat me as a 'ghair'. In my story she becomes 'apni' (the feminine form of the term).

I began this meditation with an invitation for you to write back. I hope that you will respond and participate in this discussion. It has taken me nearly 2 years to reach this point in the narrative. I have managed to complete other projects since then but 'Jean' and her pain (my pain?) has been much more difficult to write about. Why? I keep thinking about how equally painful it had been to read Tony Morrison's Beloved. But, what a wonderful title - Beloved! Wonderful because it heals even as it opens all the intimate wounds. So, as Ann Michaels says:

Questions without answers must be asked very slowly ... It's Hebrew tradition that forefathers (sic) are referred to as 'we', not 'they' ... This encourages empathy and a responsibility to the past (all our pasts, I hope, for this is crucial if we are not to collapse into ethnic cleansings of all kinds) but, more important, it collapses time ... If moral choices are eternal individual actions take on immense significance no matter how small: not for this life only.

(Michaels, 1998[1996]: 159; comment in parenthesis added)

\section{notes}

Avtar Brah teaches at Birkbeck College, University of London. This article arises out of material presented in 1997 at the conference titled 'Feminist 
Transformations', convened by the Women's Studies Institute at the University of Lancaster. I wish to thank Ann Phoenix for her insightful conversations about points raised here, and for her helpful comments on an earlier version of the article.

\section{references}

Althusser, L. (1965) For Marx, London: Allan Lane.

Althusser, L. (1971) Lenin and Philosophy and Other Essays, London: New Left Books.

Bethnal Green and Stepney Trades Council (1978) Blood on the Streets.

Brah, A. (1979) Inter-Generational and Inter-Ethnic Perceptions: A Comparative Study of English and Asian Adolescents and Their Parents in Southall, PhD thesis, University of Bristol.

Brah, A. (1987) 'Journey to Nairobi' in Grewal, S. et al. (1987) editors, Charting the Journey: Writings by Black and Third World Women, London: Sheba Press.

Brah, A. (1996) Cartographies of Diaspora, Contesting Identities, London and New York: Routledge.

Campaign Against Racism and Fascism/Southall Rights (1981) Southall: Birth of a Black Community, London: Institute of Race Relations and Southall Rights.

Frankenberg, R. (1993) 'Growing up White: feminism, racism, and the social geography of childhood' Feminist Review, No. 45.

Hall, C. (1992) White, Male, and Middle Class: Explorations in Feminism and History, London: Verso.

Hall, S. (1980) 'Race, articulation and societies structured in dominance' in Sociological Theories: Race and Colonialism, Paris: UNESCO.

Haraway, D.J. (1992) 'Ecce homo, ain't (ar'n't) I a woman, and inappropriate/d others': the human in a post-humanist landscapes' in Butler, J. and Scott, J.W. (1992) editors, Feminists Theorize the Political, New York: Routledge.

Harrison, P. (1974) 'The patience of Southall' New Society, 4 April, Vol. 28, No. 600.

Hindess, B. and Hirst, P. (1975) Pre-Capitalist Modes of Production, London: Routledge \& Kegan Paul.

Kirwan, P. (1965) Southall: A Brief History, Middlesex: Southall Public Libraries.

Kuhn, A. (1995) Family Secrets: Acts of Memory and Imagination, London: Verso.

Laclau, $\boldsymbol{\varepsilon}$. and Mouffe, C. (1985) Hegemony and Socialist Strategy: Towards a Radical Democratic Politics, London: Verso.

Lott, T. (1996) The Scent of Dried Roses, Viking.

Massey, D. (1999) 'Imagining globalisation: power-geometries of time-space' in Brah, A., Hickman, M.J. and Mac an Ghaill, M. (1999) editors, Future Worlds: Migration, Environment and Globalisation, London: Macmillan.

Michaels, A. (1998[1996]) Fugitive Pieces, London: Bloomsbury Paperbacks.

Morrison, T. (1987) Beloved, London: Chatto \& Windus.

Rose, S. (1997) Lifelines: Biology, Freedom, Determinism, London: Allen Lane Penguin Press.

Roy, A. (1997) The God of Small Things, London: Flamingo.

Skeggs, B. (1997) Formations of Class and Gender: Becoming Respectable, London: Sage.

Southall Black Sisters (1989) Against the Tide, London: SBS.

Steedman, C. (1986) Landscape for a Good Woman: A Story of Two Lives, London: Virago.

doi: $10.1057 /$ fr. 2011.73 